\begin{abstract}
TEESID: Artikkel keskendub 1890. aastal toimunud ajakirjanduslikule diskussioonile ühe muinasjutu hüpoteetilisest seosest nn Nestori kroonikaga. Diskussioon toimub korraga mitmes ajalehes, kus ilmub nii erisuguseid tõlgendusi kui ka täiendavaid teisendeid kõnealusest loost. Küsin selle järele, mis muutis selle narratiivi tolles ajahetkes nii aktuaalseks. Üheks vastuseks on käimas olnud venestusreformid, lugu oli omamoodi vahendiks, et mõtestada eestlaste kui rahvuse rolli uuenevas Vene impeeriumis - selle loo abil üritasid osalejad luua nn "väikese rahva suurt lugu".
\end{abstract}

MÄRKSÕNAD: ajakirjanduse ajalugu, folkloristika, muinasjutud, venestus, 19. sajand

\title{
0. SISSEJUHATUSEKS
}

Ennemuiste elas üks mees, kell oli kolm poega. Ta leidis metsast sinika ussi ja tõi ta lastele mänguasjaks kodu. Uss sai pea majaussiks, mängis lastega sõbralikult ja sõi nendega ühest kausist. Vanem poeg oli riiakas ja ei annud teistele rahu. Keskmine oli ussile kõige armsam, sest ta oli tasane ja osav. Aga kolmas oli truu ja ustav ja oli kõigist kõige parem. Kui poisid olid suureks kasvanud, siis ütles majauss: "Mina lähen nüüd jälle oma paika tagasi, aga teile annan ma nimed: Vanema venna nimi on Rahurikkuja, keskmise venna nimi Siniuss ja noorema nimi Truuvaar.” Siis läks uss metsa tagasi. - Kui nü̈̈d sõda tuli, siis läksivad kolm venda teistega sõtta ja võit jäi neile. Siis

$1 \quad$ Uurimus on seotud Eesti Teadusagentuuri institutsionaalse uurimisprojektiga IUT 22-5, seda toetas Euroopa Liit Euroopa Regionaalarengu Fondi kaudu (TK 145 Eesti-uuringute Tippkeskus - CEES). 
valiti nad oma vahvuse eest teiste vanemateks. Pärast läksivad nad aga võerale maale kuningateks. (Rein Ruute, 8. juuli 1890, Väike-Maarja; avaldatud Grenzstein 1890b)

1890. aasta 9. juunil ilmub ajalehes Sakala Mihkel Kampmanni artikkel "Majaussi kasvandikud. Tähelepanemise väärt Eesti muinasjutt". Artikli autor soovib tutvustada lugejatele üht rahva suust kuuldud lugu: "Rahva keskel vanavara korjates on minule üks imeline ja väga tähelepanemise väärt Eesti muinasjutt kõrvu puutunud, mida tänini üheski raamatus ega ajalehes veel leida pole olnud, millel aga suur ajaloolik tähtsus näitab olema" (Kampmann 1890). Ta rõhutab ka loo eesti algupära, "sest et teda üks niisugune vanakene on jutustanud, kes ühtegi võõrast keelt ega kirjavara ei tunne" (samas), ent nendib kahetsevalt, et loost on temani jõudnud vaid riismed.

Põhjus, miks muinasjutt laiemale lugejaskonnale huvi võiks pakkuda, peitus Kampmanni arvates selles, et peategelaste nimed (Rahurikkuja, Siniuss ja Truuvaar) on äärmiselt sarnased "esimeste Vene vürstide nimedega "Ruurik, Sineus ja Truuvaar"' (samas). Ning ehkki ta möönab, et ajaloolased peavad "nimetatud kolme vürsti ju ammu muinasjutulisteks", rõhutab ta siiski, et eesti muinasjutul võib olla ajalooline väärtus, kuivõrd see "nende kolme kuulsa vürsti kutsumise lugu veel täiendab". Lõpetuseks märgib ta lootusrikkalt, et "Missugune suur ja katkemata side ilmuks siis aga Vene- ja Eestirahva vahel kui need jutud kokku käisid ja tõeste histoorialikult tõdestatud saaksid" (samas).

Käesolevas artiklis sooviksin ma heita lähema pilgu seda artiklit ümbritsevale tekstuaalsele väljale - vaatluse alla tulevad nii suulised kui kirjalikud, avalikud kui privaatsed sõnavõtud, nii need, mis eelnesid Kampmanni artiklile, kui ka need, mis järgnesid. Artikliga jätkan ühes oma varasemas kirjutises alustatud teemat: küsimust rahvaluule kajastamisest 19. sajandi lõpu ajakirjanduses (vt Kikas 2013). On ju ka Ülo Valk esile toonud, et ajalehtedel oli väga suur roll rahvaluule kaasaegse tähenduslikkuse loomises: "Rahvaluule mõistmisele esivanemate pärandina aitas rahva seas kaasa eestikeelne ajakirjandus. Võime täheldada, et folkloori olemasolu ühiskondlik teadvustamine ja massimeedia mõjukuse kasv kulgesid paralleelselt" (Valk 2008: 61). Küsimuseks, mis mind ennast selle materjali suures enim paelub, on see, mis muutis selle narratiivi just selles ajahetkes (ja just nende inimeste jaoks) nii tähenduslikuks ja aktuaalseks.

\subsection{Ajalugu ja rahvaluule}

Diskussiooni keskseks märksõnaks on ajalugu ning küsimus rahvaluuletekstist kui ajalooallikast. Arutelu on heaks näiteks sellest, et "XIX sajandil ja XX sajandi alguses olid ajalugu ja rahvaluule omavahel põimunud vald- 
konnad, seda nii Euroopa teadusruumis kui ka Eestis" (Jaago 2014: 419). Suulisi tekste käsitleti kui võimalust kirjapandud ajaloos olevaid "lünki" täita ning usuti, et suulise pärimuse kaudu on võimalik jõuda sügavamale minevikku. Ehk üheks mõjusamaks seda lähenemist kokku võtvaks kujundiks on Jakob Hurda metafoor rahvaluulest kui "eesti rahva ajaraamatust": avaldatud ajalooraamatud käsitlevad eestlasi vähe ja kallutatult, suulise pärimuse teated annavad võimaluse eestlaste minevikust enam teada saada (Hurt 1989 [1871]: 9-25). Diskussiooni puhkemise ajaks oli see metafoor küll juba ligi kakskümmend aastat vana, kuid samalaadseid väiteid leiab ka ajas lähematest meediatekstidest (nt Truusmann 1887).

Soodsa pinnase selle idee levikuks lõid ka parajasti käimasolevad rahvaluulekogumise aktsioonid - samad ajalehed, mis osalesid diskussioonis, avaldasid ka Jakob Hurda ja Matthias Johann Eiseni kogumisaktsioonidega seotud teadaandeid. Siiski on oluline märkida, et ei Hurt ega Eisen ise arutelusse ei sekkunud. Küll aga oli diskussiooni käivitanud lugu avastatud üldisema rahvaluulekogumise käigus ning arutelus osalejatest peaaegu kõik olid ühel või teisel moel rahvaluulekogumisega tegelenud. Seega on tegu omamoodi rohujuuretasandilt lähtuva paralleelaktsiooniga, mis rahvaluulekogumise aktsioone endid otseselt ei mõjutanud, kuid see-eest võlgnes tänu juba sisse töötatud üritusele sobiva atmosfääri loomise eest.

Nimetades narratiivi "Majaussi kasvandikud" rahvajutuks või muinasjutuks, lähtun ma arutlejate antud nimetusest, pretendeerimata tähendustele, mida need mõisted kannavad tänapäeva folkloristikas. Iseenesest on lool mitmeid seoseid suulise traditsiooniga - imemuinasjutu traditsiooniga seob teda näiteks peategelaste nimetamise loogika ning üleloomuliku kasvataja kuju; samuti on olemas ka seos majaussi-pärimusega. Ometi pole mulle teada ühtegi Eesti Rahvaluule Arhiivi kogudes olevat teisendit, mis poleks diskussiooniga seotud, ${ }^{2}$ seega võib eeldada, et loo taustal on ka mingeid kirjalikke allikaid.

2 Erandiks on Peeter Südda poolt kaks aastat pärast diskussiooni Saaremaalt kogutud lugu (E 53309/15, vt EMj I 2009: 327-329 "Sinine uss" ATU 402 A*), milles on mõningaid sarnaseid motiive. Näiteks märgitakse ka seal, et kõik kolm venda on isesuguse vaimuga: "Vanem vend olnud riiakas, keskmine kaval, noorem aga tasane poiss" (samas: 327), too lugu on ühelt poolt imemuinasjutulikum kui "Majaussi kasvandikud" (sinine uss osutub nõiutud printsessiks ning lugu lõppeb keskmise venna ja kuningatütre abiellumisega), teisalt on tal ka enam seoseid majaussi-pärimusega (metsast koju toodud sinisele ussile pannakse ahju ette kausiga piima). Muinasjutuantoloogia tüübikommentaaris on esile toodud, et keskmise venna positiivsus muudab loo nn kolme venna lugude seas üsnagi ebatüüpiliseks (samas: 557), võimalik, et loo allikal on olnud kokkupuude mõne siin artiklis käsitletud juhtumi käigus avaldatud tekstiga. 


\subsection{Ajaloo (ümber)kirjutamine}

Ajalookirjutus pole kunagi neutraalne: see kõneleb sama palju olevikust kui minevikust. Ehkki ajaloo kirjapanijad apelleerivad sageli sellele, et nad on lihtsalt toimunu kirjapanijateks, tegelevad paljud neist samavõrra ka uute tõlgenduste loomise, ajaloo ümberkirjutamisega. Jaan Undusk on märkinud, et kui ajaloo üleskirjutamine "fikseerib ajaloo alguse", siis "[ü]mberkirjutusega luuakse kellegi õigus ajaloole. Ümberkirjutus on märk sellest, et igale ajaloole on olemas alternatiiv [---] et igaühest võib saada ajaloo subjekt" (Undusk 1997: 722-723). Väikerahva ajaloo "ajalookõlblikkuse" tõendamiseks ei piisa lihtsalt nende olemasolu esiletõstmisest, vaja on rakendada retoorilisi võtteid, mis tooksid esile selle rahva inimkondliku tähtsuse (samas). Unduski ideega haakub väga hästi Eda Kalmre (2012) käsitlus "väikese rahva suurtest lugudest". Selle mõistega viitab ta lugudele, mis asetavad eestlased ühel või teisel moel suurte ajalooliste narratiivide keskpunkti - need lood kõnelevad näiteks tuntud inimeste eesti päritolust või eestlaste osast suurtes ajaloolistes sündmustes. Kalmre kirjutab, et need "jutud avavad omal moel eestlaste latentse kultuurilise igatsuse parema päritolu ja isikliku ja rahvusliku õnnestumise järele" (samas: 331). Ta rõhutab, et sellised lood on enamasti küllaltki lühiajalised ja seotud konkreetsete päevakajaliste sündmustega; sageli kerkivad nad aga esile ühel või teisel moel ebastabiilsetes oludes. Samas rõhutab Kalmre, et hoolimata lugude endi efemeersusest võib üldisemas kontekstis rääkida jätkuvast traditsioonist. "Me ei pruugi neid fantaasialugusid ju eriti tõsiselt võtta, ometi artikuleerivad just need muistendi ja kuulujutu vormis lood eestlaste personaalseid ja rahvuslikke vajadusi ning igatsusi teatud (aja) perioodidel" (samas).

Ka kõnealune diskussioon toimus rahvuse seisukohast keerulisel ajal 1880. aastate keskpaigas alanud nn venestuse ${ }^{3}$ kõrgajal. Tsaaririigi jaoks olid venestusreformide eesmärgid peamiselt administratiivsed - soov Balti kubermange tugevamalt keskvõimu külge siduda, nn Balti erikorda nõrgendada (Raun 2009: 123, nn administratiivsest venestusest vt samas: 131-138). Kõige sellega kaasnes aga ka tsensuuri tugevnemine, poliitilise tegevuse piiramine, kahtlustav suhtumine mittevene rahvaste rahvuslikesse ambitsioonidesse ning - kohalike keelte (eesti ja saksa) kadumine ametlikust asjaajamisest, sh muutusid venekeelseteks kohtusüsteem (1885) ja kool (1887) (samas: 139-151); vene ametnikud nimetasid eesti

$3 \quad$ Mitmed ajaloolased on kutsunud üles loobuma venestusest kui terminist ja ajastunimetusest, viidates mõiste liigsele ebamäärasusele ja hinnangulisele (vt nt Miller 2009, Brüggeman 2010, Karjahärm 2012). Parema alternatiivi puudumisel olen oma artiklis siiski venestuse mõiste juurde jäänud - loodan aga, et minu käsitlus aitab omalt poolt samuti näidata seda, et nn venestuse mõju võis olla üsnagi eripalgeline. 
keelt murdeks, mitte keeleks (samas: 137). Venestust õigustati ka vastavate ajalookäsitlustega, mis rõhutasid seda, et eesti ja vene rahvuste vahelised kultuurilised erinevused on nii väikesed, et eestlaste venestumine toimub täiesti valutult ja loomulikult; näiteks rõhutab Jefgrad Tšešihhin oma raamatus "Balti krai lühike ajalugu" (1884), et eesti ala "pole midagi muud kui Vene riikliku ala jätk Balti mere ääres, mida ei eralda sellest mingid looduslikud tõkked" (op. cit. Karjahärm 1997: 31-33).

Siinjuures on oluline, et Tšešihhini käsitlus lähtub samast allikast, millele vihjab oma artiklis ka Kampmann - Vana-Vene kroonikast, millele tänapäeval viidatakse nimetusega "Jutustus möödunud aegadest", diskussioonis kasutatakse aga hüpoteetilisele autorile viitavat nimetust "Nestori kroonika". Sündmus, millele arutelus keskendutakse, on kõne all olevas kroonikas esitatud nii:

Aastal 6370 (862) kihutati varjaagid tagasi mere taha, ei antud neile maksu, vaid hakati end ise valitsema. Ei olnud õigusepidamist, suguharu tõusis suguharu vastu, ja nende vahel oli suur riid ja segadus, ja nad hakkasid omavahel sõda pidama. Ja nad ütlesid üksteisele: otsime endale vürsti, kes valitseks meie üle ja mõistaks kohut. Ja nad läksid üle mere varjaagide juurde, keda kutsuti russideks, nagu teisi kutsuti svealasteks, norralasteks, anglideks või götalasteks. Ja tšuudid, sloveenid, krivitšid ja vepslased ütlesid russidele: meie maa on suur ja lai, kuid korda ei ole seal teps, tulge valitsege meie üle ja olge meile vürstideks.

Ja kolm venda valiti nende seast, need võtsid russe enesega kaasa ja tulid. Kõige vanem vend Rjurik asus Novgorodi, teine, Sineus, Valgjärvele, ja kolmas, Truvor, Irboskasse. Nende järgi sai Venemaa oma nime. (Karjahärm, Adamson 2008: 22)

Ent kui tuntud oli see sündmus 1890. aastate eestlastele? Minu katsed leida viiteid sellele sündmusele ja vürstide nimedele 19. sajandi eestikeelsest kirjasõnast pole olnud väga tulemuslikud. Kõige põhjalikumalt tutvustavad sündmust eesti keeles 1855. aastal ilmunud "Eesti rahva kalender" ning Jakob Lindenbergi raamat "Vene rahvas ja vene riik" (1872), lisaks on mõned viited üldajalugudes (nt Körber 1860, P. Jakobson 1885), kuid näiteks kalendrite kronoloogilistes ajatabelites vürstide kutsumist polnud (vt nt Viires 2001). ${ }^{4}$ Loomulikult ei saa väita, et eestlaste ajaloo käsitlustes

$4 \quad$ Omaette viiteks sellele, et vürstide tegevus ja nimed ei olnud eestikeelses kirjasõnas väga tuntud, on see, et puudus ühtne traditsioon nimede ladina tähestikus esitamiseks. Nii esineb nimi Рю́рик kujul Rürik (Lindenberg 1872) ja Ruurik (C. R. Jakobson 1875, P. Jakobson 1885), nimi Синеус kujul Sineus (Lindenberg 1872, C. R. Jakobson 1875) ja Siineus (P. Jakobson 1885) ning Tрувор kujudel Truvor (Lindenberg 1872) ja Truuvor (C. R. Jakobson 1875, P. Jakobson 1885). Jääb mulje, et iga kasutaja jaoks on lähteks kirillitsa vorm, mida siis oma parema äranägemise järgi teisendatakse. 
impeeriumitasandile üldse ei viidatud, kuid valdavalt oli selle kokkupuute alguseks aasta 1710, mil Eesti ala liideti Vene riigiga; teiseks oluliseks daatumipaariks oli 1816/1819 (pärisorjuse kaotamine Eesti- ja Liivimaal, vt nt Eisen 1877); lisaks viidati mõningates 19. sajandi ajaloo-käsitlustes venelastele seoses kahe rahva suhetega muistse vabadusvõitluse ajal, kuid neis rõhutati alati eestlaste kui rahvuse eraldiseisvust (vt Kukk 2009: 194-197). Seega: arutelu keskmesse kerkis sündmus, mida tavapärastes eestlaste ajalugudes esile ei toodudki, küll aga oli see impeeriumi kui terviku seisukohalt olulise tähendusega - seega võib diskussiooni vaadelda kui omamoodi katset küsida selle järele, milline on eestlaste (kui eraldiseisva rahva) positsioon (venestusaegses) impeeriumis kui tervikus.

\section{ARUTELU KRONOLOOGIAST}

Esimeseks avalikuks vastukajaks Kampmanni kirjutisele on 28. juunil Eestimaa Kubermangu Teataja kultuurilisas ilmunud artikkel, mis annab lühiülevaate Kampmanni kirjutisest, kuid lisab ka mõningaid omapoolseid märkusi (Eestimaa Kubermangu Teataja 1890). Kuna viidatud väljaanne on peamiselt ametlikke teadaandeid sisaldav venekeelne nädalaleht, tõstab selle sekkumine diskussiooni hoopis teisele tasandile - algselt pigem kohaliku ambitsiooniga ajalehes ilmunud tekst liigub riikliku (s.o Vene impeeriumi) tasandi inforuumi.

Eestimaa Kubermangu Teatajas ilmunud loost ajendatuna võtab Ado Grenzstein teema üles ka Olevikus. 9. juuli ajalehes annab ta ülevaate Eestimaa Kubermangu Teatajas ilmunust ning tutvustab Eesti lugejat silmas pidades ka Nestori kroonikas olevat teavet vürstide kutsumisest (Grenzstein 1890a). Nädal hiljem ilmub reportaaž külaskäigust Kampmanni informandi Rein Ruute juurde (Grenzstein 1890b). Grenzstein ütleb ka otse välja selle, millele lugu justkui vihjavat näib: "On ta tõeste Eesti muinasjutt, siis täiendab ta üht tähtsat Vene muinasjuttu ja on sellepärast väga tähtjas: Vene esimesed vürstid Ruurik, Sineus ja Truvor oleksivad siis Eestlaste keskest Venemale läinud" (samas). Mõlemas artiklis pöördub Grenzstein rahvaluulekogujate poole üleskutsega kõik vähegi haakuvad lood kirja panna ja talle saata. Olevikku laekub kolm teisendit, kirjapanijateks Peeter Koit, Johan Pihlakas ja Voldemar Lurich (Koit 1890, Pihlakas $1890^{5}$, Lurich 1890).

Septembris sekkub arutellu keeleteadlane ja tsensor Jüri Truusmann. Tema kirjutis ilmub esmalt venekeelsena Eestimaa Kubermangu Teatajas ning hiljem tõlkena Eesti Postimehes ja Valguses (Truusmann 1890).

$5 \quad$ Pihlakas saatis oma kirjutise lisaks Olevikule ka Sakalale. Kuna vahemikus augustist septembrini Sakala ei ilmunud, jõudis Sakalale saadetud kaastöö trükki alles 27. novembril 1890, selleks ajaks oli diskussioon juba lõppenud. 
Truusmann jagab eelnevate kirjutajate tundmust, et tegu on teaduse jaoks olulise leiuga. Siiski häirib teda Grenzsteini sõnastatud järeldus, nagu võiks loo olemasolu viidata muistsete vürstide Eesti päritolule: "Eesti ajalehtedes ja "Eesti gubermangu ajalehes" seisivad sellest muinasjutust kirjatükid, milledest silmnähtavalt mõte välja paistis, tunnistada, et Veneriigi asutajad, nimelt Ruurik, Sineus ja Truvor Eestist on tõusnud; iseenesest on nüid mõista, et sarnane vaba muinasjutu seletamine tõsistele Venelastele ainult arusaamatuseks võis jääda" (samas). Erinevalt teistest osalistest, kes õhutasid lugejaid arutelus kaasa lööma ning uusi teisendeid otsima, on Truusmanni kirjutise rõhutatult teaduslik argumentatsioon pigem suunatud edasiste arutelude lõpetamisele.

Hajusamaid viiteid "Majaussi kasvandikele" leiame ka järgnevatest aastatest. Näiteks ilmub aasta hiljem Olevikus Jaan Jungi artikkel "Veel kord Eestlaste ussiusust ja Ruuriku muinasjutust" (1891) ning diskussioonile viitab oma "Üleüldises Isamaa ajaloos" ka Andres Saal (1893: 118-120). Siinses artiklis piirdun 1890. aasta juunist oktoobrini ilmunud kirjutiste analüüsiga.

\section{ADO GRENZSTEIN VERSUS JÜRI TRUUSMANN}

Ehkki viitan vaadeldavale sündmusele kui arutelule, pole kõik esiletoodud kirjutised otseselt üksteisega dialoogis, pigem võime rääkida sellest, et mõned osalised ignoreerivad teineteise väljaütlemisi üsnagi teadlikult. Nii ei leia me Grenzsteini Olevikust ühtegi viidet Jüri Truusmanni sõnavõtule - seda hoolimata sellest, et Olevik näib olevat võtnud eesmärgiks kõike teemaga seonduvat vahendada, ning mitmed ajalehele laekunud täiendavad teisendid ilmuvad pärast Truusmanni artiklit (nt Koit 1890, Lurich 1890, Jung 1891$)^{6}$. Kuid ka Truusmanni artiklist ei leia me otseseid viiteid Olevikule - Truusmanni arutelu keskmes on küll Grenzsteini poolt Olevikus avaldatud teisend (1890b), kuid Truusmann ei tutvusta teisendit mitte Oleviku kaudu, vaid viitab allikana Kampmannile (kes teisendi kogumise juures tõesti kohal oli); ka ilmuvad Truusmanni artikli eestikeelsed versioonid ajalehtedes (Valgus ja Eesti Päevaleht), mis muul moel diskussioonis ei osale.

Teades, et Grenzsteini ja Truusmanni omavahelised suhted olid kõike muud kui head, pole nende teineteise ignoreerimine ilmselt üllatav. Torkab siiski silma, et positsioonid, millele Truusmann ja Grenzstein diskussiooni käigus asetuvad, pole üldsegi mitte teineteist välistavad. Grenzstein esitab end vahendaja ja organiseerijana, kellenagi, kes töötab selleks, et tõelistel teadlastel oleks võimalik teemale hinnang anda. Innukus, mil-

\footnotetext{
6 Truusmanni sõnavõttu ignoreerib ka Andres Saal (1893: 118-120).
} 
lega Grenzstein uurimist edendama asus, oli kooskõlas nii tema organiseerijaloomusega kui ka sellega, et Olevik oli omas ajas üks rahvaluulesõbralikumaid ajalehti - seal avaldati meeleldi rahvaluulekogumisega seotud teadaandeid-üleskutseid, mida sageli täiendasid toimetusepoolsed "tähendused". Ka ilmus Oleviku veergudel päris palju rahvaluulelist ainest ning rahvaluulekogujate kogumispäevikuid. Truusmann omakorda kõneleb ametniku-teadlase topeltpositsioonilt - esimese aktualiseerib märkusega, et diskussiooni eelnev kulg võis "tõsistele Venelastele ainult arusaamatuseks [---] jääda” (Truusmann 1890), teise aga viidetega teiste teadlaste töödele. Tema teadlase-autoriteeti tugevdas seegi, et ta oli haakuval teemal ka juba varem avalikult sõna võtnud - 1887. aastal Eesti Kirjameeste Seltsis peetud ettekande "Kust ja kudas algab Eesti rahva ajalugu" tekstist võib leida mitmeid detaile, mis "Majaussi kasvandikest" lähtuvas diskussioonis arendamist leidsid. ${ }^{7}$

Seega: ideaalis oleks võinud Truusmann olla see teadlane, kes Grenzsteini juhitud eeltööd üle võtab ning Grenzsteini poolt välja käidud hüpoteesile (muistsed vürstid olid Eestist pärit) teadlase-positsioonilt lähtuva kinnituse annab. Seda minu oletust toetab ka asjaolu, et tõenäoliselt oli just Truusmann see, kelle mõjul teema üleüldse Oleviku veergudele jõudis.

Nimelt tuleb ühest Kampmanni kirjast Andres Saalile välja, et Grenzsteini huvi teema vastu tekkis teatava viivitusega. Kirjas märgib Kampmann, et ta soovis oma artiklit avaldada Olevikus, kuid Grenzstein lükkas selle tagasi. Kampmann möönab, et "eks ettevaatamine ole nüüd igal pool”, kuid on siiski nördinud, et pidi nii olulise kirjutise "tähtsuseta ja vähe loetavas lehes ära trükkima." Seega ei avastanud Grenzstein seda teemat Eestimaa Kubermangu Teatajast (nagu ta oma artiklis püüab välja näidata), vaid oli materjalidega juba varem tuttav. Teades, et Grenzstein oli tol ajal võimude kõrgendatud tähelepanu all, võib eeldada, et kaastöö tagasilükkamise põhjuseks võis olla Kampmanni viidatud ettevaatus (vt nt Arukaevu 1999: 113).

7 Kõnes tõdes Truusmann, seniste geograafiliselt piiritletud ajalugude asemel vajab eesti rahvas $\mathrm{r}$ a h v u s lik k u ajalugu - narratiivi, mis hõlmaks lisaks Läänemere ääres toimunule ka seda, kuidas nad Venemaa avarustest oma praegusele asualale rändasid. Kõnealuse diskussiooni seisukohast on põnev, et 1887. aasta kõnes mainib Truusmann möödaminnes mõningaid detaile, mis 1890. aasta artiklis selgema tähenduse omandavad (eestlaste kuulumine tšuudide hulka, vürst Truvori valitsusaeg). Pikemalt on 1887. aasta tekstis juttu Russa vallast ja Russapapast näib, et kogu info selle muistse valla kohta pärinebki sellest Truusmanni artiklist.

$8 \quad$ M. Kampmann A. Saalile 1. dets. 1890, EKLA f 113, m 14:2, 1 2/2. Kampmann viitab ka, et seoses "Majaussi kasvandikega" nimetasid Sakalat "kõik Vene lehed”. Seega võib eeldada, et venekeelses meedias oli sündmuse kandepind mõnevõrra laiem kui vaid mulle teada olev Eestimaa Kubermangu Teataja. Samal ajal on huvitav, et näiteks Truusmann viitab vaid sellele lehele. 
Kuid mis pani Grenzsteini meelt muutma? Üheks vastuseks on kindlasti see, et teemat kajastati Eestimaa Kubermangu Teatajas - ajalehes, mis oli kohalikuks riigivõimu häälekandjaks. Teisalt on oma osa kindlasti ka Truusmannil. Truusmanni artikkel ilmus küll alles septembris, kuid veel enne Eestimaa Kubermangu Teataja artikli ilmumist (juba 24. juunil) on ta saatnud Kampmannile kirja, milles küsib täpsemat teavet loo ja jutustaja kohta. Truusmann palub loo uut kirjapanekut ning rõhutab, et tõelise teadusliku veenvuse omandab muinasjutt alles siis, kui selle tagamaid kohtuliku täpsusega uuritakse:

Minu arvates on see jut ülitähtjas ja sellepärast peaks teda teaduse meestele nii ette panema, et mingisugust kahtlust tema alguspäralisuse kohta ei võiks tõusta. Muidu võiksivad mitmedki teda koguni tähelepanemata jätta ja kunstlikuks luule tööks arvata. Et niisugust kahtlust tagasi hoida, peab selle vana juttuga nii ümber käima, nagu kohtu uurija sündmusega, mis veel kõikipidi tõendamata on. (J. Truusmann M. Kampmannile 24. juuni 1890, EKLA f 36, $\mathrm{m}$ 2:10, 1 1/1)

Tegu oli küll erakirjaga, kuid näib tõenäoline, et Kampmann võis kasutada seda argumendina Grenzsteini ümberveenmiseks. ${ }^{9}$ Kirja mõju võis muidugi olla üsna mitmetine. Truusmanni kui riigiametniku huvi võis olla Grenzsteini jaoks märguandeks, et tegu on ohutu teemaga. See võis aga tekitada Grenzsteinis lootuse, et Truusmanni huvi teema vastu lähtub samast vaatepunktist kust temagi oma ning järgnes Grenzsteini soov olla esimene, kes hüpoteesi (eestlased kui vürstide päritolurahvus) välja käib. Kui aga Truusmann võttis siiski avalikult teistsuguse positsiooni, jäi Grenzsteinil ainsaks võimaluseks teda ignoreerida.

$9 \quad$ Üheks viiteks, et Grenzstein oli selle kirjaga tuttav, on see, et Olevikus avaldatud versioon majaussi loost on kirja pandud, toetudes juhistele, mis Truusmann Kampmannile saadetud kirjas andis. Kirjas andis Truusmann näiteks järgnevaid juhiseid: 1) üleskirjutus peab jälgima jutustaja sõnakasutust ning hõlmama ka jutustaja kommentaare; üleskirjutaja ja jutustaja sõnad peavad olema selgelt eristatavad; 2) vaja on andmeid loo päritolu kohta: kellelt jutustaja lugu kuulis; ning võimalusel ka täpsemaid teateid algse allika päritolu ja tausta kohta (Truusmann rõhutab eriliselt rahvuse küsimust ehk siis seda, et on vaja veenduda, et lugu ei pärineks mõne sisserännanu käest); 3) vaja on täpseid andmeid loo geograafilise leviku kohta; 4) vaja oleks jutustaja elulugu, mille juures tuleb erilist tähelepanu pöörata küsimusele "kas ei olnud kuidagi võimalik, et juttustaja on raamatutest ehk mujalt midagi Rürikist, Sineusist ja Truvarist kuulnud" (M. Kampmann A. Saalile 1. dets 1890, EKLA f 113, m 14:2, 1 2/2). On küllaltki põnev, et tänu Truusmanni juhistele on ajakirjanduses ilmunud versioonid kontekstualiseeritumad kui samade lugude Hurdale saadetud versioonid. 
Kokkuvõttes võib öelda, et diskussioonil on kaks keset. Neist üks lähtub Truusmannist, kes oma riigiametniku staatust kasutades levitab oma sõnumit võrdlemisi laialt, teine aga Grenzsteinist, kes oma ajaleheomani$\mathrm{ku}$ staatusele toetudes mobiliseerib lugejaid kaasa mõtlema. Järgnevalt vaatlengi ma lähemalt osaliste sisulisi argumente - kõigepealt seda, mis toimus Grenzsteini juhitud Olevikus ning seejärel Truusmanni sõnavõtte. Eestimaa Kubermangu Teatajas ilmunud teksti olen ma pannud kokku Olevikuga, ehkki asjaolu, et samas ajalehes ilmus ka Truusmanni artikli esmaversioon, muudab selle väljaande asendi ambivalentseks. Nende kahe avalikus kirjaruumis nähtava keskme järel vaatlen ma natuke lähemalt aga seda, mis eelnes loo "Majaussi kasvandikud" meediasse jõudmisele.

Siiski on oluline meeles pidada, et teatud üldisemad võtted, mis neid kaht keset koos hoiavad, on samad. Esiteks: mitte ükski arutelus osalevatest inimestest ei puuduta võimalust, et nimede sarnasuse lähteks on juhuslik kõlaline sarnasus. Kõik nad jagavad usku sellesse, et sõnade etümoloogia selgitamine on oluline vahend minevikule lähemale jõudmiseks ning rahvaste/keelte omavaheliste ajalooliste suhete kinnitamiseks. Teiseks kohtlevad nad kõik muinasjuttu sünekdohhiliselt. Narratiivi tasandil tähendab see eeldust, et meieni jõudnud lugu on vaid osa kunagisest tervikust, rahvuse tasandil aga seda, et sünekdohhi täitmiseks sobivad detailid ei pea pärinema ilmtingimata muinasjutust endast, küll aga peavad nad olema seotud Eesti ja eestlastega (sünekdohhi printsiibist vt Undusk 1995: 669-670, sünekdohhi täitmisest vt samas: 679, 749).

\section{ADO GRENZSTEINI OLEVIK: ÜKSIKDETAILID JA NARRATIIVID}

\subsection{Kahe rahva lugude kõrvutamine}

Arutelu algatajad (nende hulka võib arvata Kampmanni, Grenzsteini ja Eestimaa Kubermangu Teataja kirjutaja) lähtuvad eeldusest, et narratiivselt tähendustatud nimed (s.o Rahurikkuja, Siniuss ja Truuvaar) on vanemad ning neid, mida tajutakse mittetähenduslikena (Ruurik, Siniuss, Truuvaar) vaadeldakse kui võõras keskkonnas häälduspärastunud versioone. Näiteks seletab Grenzstein teisendust Rahurikkuja > Ruurik nõnda: "Sõnas Rahurikkuja öeldakse h ja uja nii kergeste välja, et nad võera kõrvas peagi ära kauvad, nii et ainult Raurik selgeste välja kuuldub, millest kergeste Ruurik võis saada" (Grenzstein 1890a).

Siiski ei jää arutlejad üksnes nimede juurde, vaid üritavad leida ka muid võimalusi kahe narratiivi ühendamiseks. Näiteks kerkivad küsimused sellest, kes on Russid (rahvas, kelle hulgast kroonika teatel vürstid pärinevad) ning millise mere tagant nad tulid. 
Russi nime tähenduseni jõudmiseks kasutab Eestimaa Kubermangu Teataja artikli autor (1890) üheaegselt kaht võtet. Esiteks pakub ta välja konkreetse geograafilise punkti: Eesti idaosas oli varasemalt Rusti (või Russi - artiklis on kasutatud neid vaheldumisi) vald, kus kunagi elas ka talumees, keda kutsuti Russi papaks. Teiseks pakub ta välja kaks võimalust selle valla nimetuse eesti keele põhiseks tähenduslikustamiseks: rootsi > russ ja rusikas > russ. Neist esimene viitaks, et Russi valla asutajad ja elanikud pärinesid Rootsist; teine aga viitaks selle valla elanike erakordsele jõule - rusikas osutaks laiendatult (rusika)jõule. Ehkki artiklis seda ei öelda, pärineb teave Russi valla kohta tõenäoliselt ülalviidatud Truusmanni ettekandest "Kust ja kudas algab Eesti rahva ajalugu" (1887), kuid Truusmann pole nimetust kuidagi etümologiseerinud.

Neid Eestimaa Kubermangu Teatajas ilmunud ideid tutvustab oma lugejatele ka Grenzstein. Aga kahest väljakäidud etümoloogiast toob ta esile vaid ühe - rusika ja rusikajõuga seonduva (Grenzstein 1890a). Omalt poolt lisab ta aga küsimuse kõnealuse mere võimalikust asukohast. Ka temal on välja pakkuda kaks lahendust: esiteks võib "mereks" olla Peipsi järv, teiseks aga võib kasutatud väljend olla üldisem viide välismaalt pärinemisele: "Mis meri see oli millest räägitakse, seda ei tea. Võimata ei ole see mitte, et see Peipsi järv oli, mida Venelased hästi tundsivad. Pääle selle ei ole sugugi tarvis mõtelda, et kolm venda just tagast mere toodi, sest 3 a море tähendab Venekeeles ka võerast maad (заморские товары - võeramaa kaubad)" (samas). Peipsi hüpoteesi juures on oluline see, et see toetas ideed muistsest Russi vallast kui müütilise russi rahva asukohast - asus ju mainitud vald Peipsi kõrval.

\subsection{Narratiivid kui vastused}

Vastusena Grenzsteini üleskutsele koguda kokku kõik "Majaussi kasvandike" teisendid laekus Olevikku kolm kaastööd - arvestades seda, kui palju inimesi sel ajal aktiivselt rahvaluulekogumisega tegeles, polnud seda muidugi palju. Et aga vürstide kutsumisega seonduv oli eestikeelses kirjasõnas nii vähe esindatud, on tõenäoline, et suur osa inimestest ei suutnud selle teemaga suhestuda.

Johan Pihlakas saatis pikema kirjutise, mis sisaldas tema enda positsioonilt kirjutatud arutleva sissejuhatuse, terviknarratiivi (teisend JP2 ${ }^{10}$ ) ning kirjeldava fragmendi (teisend JP1). Voldemar Lurich saatis kirjutise, mis sisaldas terviknarratiivi (teisend VL1) ning seda täiendava üksikmotiivi (teisend VL2). Peeter Koidu kirjapanek on fragmentaarne narratiivi

10 Selleks, et artikleid ning nende hõlmatavaid terviknarratiive paremini eristada, kasutan lugudele viitamiseks lühendeid, mis koosnevad üleskirjutaja initsiaalidest ning kui sama inimene on kirja pannud mitmeid lugusid, siis lisandub ka number. Täpsem ülevaade kõigist kirjapandud lugudest on artikli lisas. 
põhipunktide edastamine (teisend PK) - sellise katkendlikkuse põhjuseks võis olla allikmaterjali iseloom, kuid tõenäolisem on Koidu kogenematus rahvaluulekogujana - ta oli ainus diskussioonis osaleja, kellel puudus varasem kokkupuude rahvaluulekogumisega (Pihlakas ja Lurich olid mõlemad Hurda rahvaluulekorrespondendid).

Pihlaka ja Lurichi tekstide suurem ladusus (võrrelduna Koidu kirjapanekuga) ei tulene üksnes narratiivi suuremast sidususest, vaid ka sellest, et tekstidest on näha kirjapanijate soov pakkuda kirjapandava kaudu vastuseid mõningatele diskussiooni varasemas osas esile kerkinud küsimustele. Siiski on nad kursis eelkõige Olevikus toimunuga, Eestimaa Kubermangu Teatajas ilmunut teavad nad vaid Grenzsteini vahendatuna.

Üheks varasemas diskussioonis üleskerkinud detailiks, millele nii Pihlakas kui Lurich konkreetsemalt tähelepanu pööravad, on Russi rahva nimi.

Pihlakas toob "Russi" küsimuse esile kui ühe põhjuse, miks ta üldse oma loo kirja panna otsustas: "Mis aga uurimise all olevasse jutusse "Majaussi kasvandikud" ja "Russi" nimesse puudub, selleks toon paar lapsepõlves Jüri kihelk. kuuldud lookest..." (Pihlakas 1890). Tõsi - selle sissejuhatuses oleva märkuse tausta muudab mõnevõrra hämaraks see, et kirjapandud jutud nimetust "Russ" ei sisalda. Ainus võimalus seda märkust lugudega siduda on eeldada, et Pihlakas soovis kinnitada tõlgendust russ $<$ rusikas $<$ rusikaramm - tema kirjapandud lugudes pole vennad mitte lihtsalt osavad ja tugevad, vaid nende tugevus seisneb rusikavõitluse valdamises - "Nõnda hakatud teisa rusikamiesteks üidma ja pandud sõea äal teisa õpetama” (JP2).

Lurichi pakutud "Russi" tähenduse tõlgendus pole nii otseselt dialoogis varem ajakirjandusest läbikäinud võimalustega, siiski paistab silma see, et ta on pidanud vajalikuks selle sõna oma kirjapanekusse põimida: episoodis, kus rohuuss hammustab Rahurikkuja poega keelde - on ta sõnale rohuuss lisanud sulgudes märkuse “(Русь?)". ${ }^{11}$

Lurich ja Pihlakas on oma tõlgendusi välja pakkudes küll võrdlemisi tagasihoidlikud - üks teeb vihje sissejuhatuses, teine lisab sulgudesse paigutatud märkuse -, kuid ilmselgelt soovivad mõlemad anda märku, et nad mõtlevad aruteluga kaasa.

11 Küsimärk näib olevat Grenzsteini lisandus - sama loo Hurdale saadetud versioonis (VL3) küsimärki pole. Teisendite VL1 ja VL3 vahel on veel üks teinegi erinevus. Nimelt on lause "Nüüd tulivad vaenlase maalt vendade juurde saadikud oma venedega ja palusid neid nende juure kuningateks tulla" (VL1) ajalehe versioonis sõna venedega esitatud sõrendatult. Tõenäoliselt on tegu Grenzsteini sooviga juhtida tähelepanu sellele, et lugu viitab "välismaa" paiknemisele vee (mere) taga. Kahjuks pole mul õnnestunud leida Lurichi Olevikule saadetud teksti käsikirjalist versiooni - nime järgi otsides tuleb välja vaid kaaskiri (V. Lurich A. Grenzsteinile 25. nov. 1890, EKLA f 48, m 12, 1 217-218). 
Siiski ei piirdu nende panuse erilisus vaid tagasihoidlike viidetega Russi nimetuse võimalikele tähendustele. Nende tekstides kerkib esile ka üks muust arutelust pigem kõrvale jäänud teema - "Majaussi kasvandike" suhe maja-(kodu-)ussi pärimusega (teema osakaalu nende kirjapanekutes suurendab seegi, et ka terviknarratiividele lisatud fragmendid JP1 ja VL2 keskenduvad ussidega seonduvale). Nii Lurich kui Pihlakas on lisanud lugudele majaussi pärimust visandava sissejuhatuse, ning ka majaussi sinisel värvil on nende kirjapanekutes narratiivne funktsioon. Nii selgitab Pihlaka kirjapanekutes õiget värvi majaussi omamine vendade tugevust: teisendis JP1 annavad rammu kõik majaussid peale mustade, teisendis JP2 on vajalik sinise ussi omamine:

Vanaste peetud paljudes majades ussa, keda õnneandjateks arvatud. Neid olnud igate karva üksi muste mitte, keda õnnetuteks peetud. [---] Ka teistega rammukatsudes ehk sõjas sõdides jäänud ussidepidajad alati võitjateks, mispärast neid rammumeesteks hakatud hü̈̈ma, kuna teisa, kes esimestele kadeduse pärast muste ussa salamahti majasse kannud, tembumeesteks nimetatud. (JP1)

Ennemuiste old palju häid ussisi old, kes kohe toas eland, ega kedagi põle ammustand. Kõige paremad old valged ja sinised ussid:

Valged vara jagajada, Siniseist situst (tugevust) soadakse.

Kell valge uss old, saand rikaks, kell sinine, selle vasta põle (jõu poolest) kiegi moa pial soand. valgeid ussisi old aga väga vähe, siniseid viel vähem. (JP2)

Lurichi kirjapanekus on vastandus sinise majaussi ning mustjasroheliste tigedate rohuusside vahel. Loos tuleb esile, et sinine majauss mängib lastega, sööb nendega samast kausist ning jagab neile õpetusi, loole eelnevas sissejuhatuses on ka otsesõnu märgitud, et "kirjud ja sinakashallid ussid toovad õnne" (VL1). Vaenulik uss ilmub ülalviidatud hammustamisepisoodis (sündmus kordub ka teisendis VL2):

Pärast sõda võttis Rahurikkuja omale naese. Kui esimese poja sai, keda isa järele ka Rahurikkujaks hü̈̈ti, tuli metsast "Rohuuss" [---], kes kõhu alt rohekas, muidu mustjas oli, tuppa. See oli ise tige uss, nagu rohetismustad ussid ikka ja hammustanud noore Rahurikkuja keele otsast tüki ära, mis pääle ta plagama pani. Selle pärast ei võinud poiss ka hästi rääkida. (VL1) 


\section{JÜRI TRUUSMANN: PÜÜD LÕPLIKU SELETUSE POOLE}

\subsection{Eestlased kui vahendajad Skandinaavia ja Venemaa vahel}

Jüri Truusmann ei jaga teiste osaliste usku eesti muinasjutu tegelaste nimede esmasusse - tema käsitluses on eestlased hoopis need, kes teistelt keelelisi vorme sisse laenavad. Nii viitab ta artiklis, et eestlaste ja venelaste pikaaegsetele headele suhtele viitab see, et "Eestlaste keeles on palju sõnu olemas, mis kaubitsemisesse puutuvad ja Venelaste käest laenatud on" (Truusmann 1890). Vürstide nime päritolu kohaks peab ta aga hoopiski Skandinaaviat: nime Ruurik eellaseks on vana skandinaavia nimi Rurik (või Rorik) ning Sineusel Sineut (või Siniut). Skandinaavia-kesksest vaatepunktist kritiseerib Truusmann ka teisi arutelus üles kerkinud ideid. Nii kirjutab ta näiteks, et meri, mille tagant vürstid tulid, ei olnud Peipsi järv, vaid Läänemeri:

Igal olekul ei või aga mitte milgi kombel meri, mille taga vürstide elu paik enne kutsumist oli Peipsi järv olla, mida ajaloos ka millalgi mereks ei nimetata ja mis Novgorodi Slaavlastele nii hästi tundud oli, et nad oleksivad võinud kutsutud vürstide elu kohta kindlaste ja selgeste tähendada, kui nad tõeste selle järve ligi kaudsuses oleksivad elanud. Et Ruuriku ligemad järel tulijad sagedasti Rootsist abi otsima läksivad, temaga sõbralises ja sugulaslises läbi käimises elasivad, on nähtav põhjus, mis kutsutud vürstide kodumaad ainult Balti mere tagant Rootsimaalt otsida laseb. (Truusmann 1890)

Russi nime algupäraks peab ta nimetust Rootsi: "Nimi Russ ehk Russi tuleb sõnadest Ruotsi, Ruots, Roosi, Russi - kuidas õhtu poolsed Soomlased Rootslasi ja Rootsimaad nimetavad" (samas). Nõnda toetab ta seda Eestimaa Kubermangu Teatajas väljapakutud tõlgendust, mida Grenzstein oma ülevaates ignoreeris.

Eelnev ei tähenda, et Truusmann eitab eesti muinasjutu väärtust ajaloolise allikana; ta rõhutab, et "Suurt luule võimu ja rahva vaimu sünnituste iseäralist elavust ülestunnistades on eesti muinasjutt ka ajaloolist tõtt alal hoidnud" (samas). Üks osa sellest tõest on peategelaste nimed - Truusmann on nimede samasuses nii kindel, et erinevalt teistest osalistest, kes viitavad muinasjutule pealkirjaga "Majaussi kasvandikud", nimetab Truusmann seda "Muinasjutuks Rürikist, Sineusist ja Truuvorist"12.

12 Nimede samasusele juhib ta tähelepanu ka otsesemalt: "Eesti muinas jutul on iseäraline tähendus, mis väärt on, et Vene ajaloo tundja oma tähelepanemist tõeliselt tema peale heidaks. See tähendus on selles, kuidas Eesti rahva mälestuses Vene riigi asutajate nimed alal hoitud on peaaegu seesama suguses kujus, missuguses neid Vene ajaloo isa Nestor alles XI aasta saja sees ülesse pani” (Truusmann 1890). 
Truusmanni arvates on vaadeldav muinasjutt vaheetapiks vene ja skandinaavia versioonide vahel. Viimast näitlikustab ta viitega teisendusele Sineut $>$ Sineus, märkides, et kuna muutus $t>s$ on iseloomulik just soomeugri keeltele, on keeleteadlane Arist Kunik ${ }^{13}$ juba varem välja pakkunud, et venelased võisid nime Sineus laenata soome sugu rahvaste vahendusel, Truusmann leiab, et muinasjutt "Majaussi kasvandikud" on veenvaks tõendiks selle versiooni kasuks. Seega kujutab ta teisenduste suunda ette järgnevuses: Sineut > Siniuss > Sineus. Lisaks leiab Truusmann, et tähendus, mis nimedele eesti keeles on antud, on kooskõlas ajaloolise tõega - viimane kehtib eriti seoses Rahurikkujaga:

Eesti muinas jutus on, nagu näha, ka kutsutud vürstide karakterist tume mälestus alal. Kui vanema venna nimi Rahurikkuja mitte juhtumise kombel ei ole tekkinud selle läbi, et Rootsi nimed Eesti nimega kokku kõla poolest sarnadust on, mis vähem tõenäuline on, sest et muinasjutus räägitakse Ruurikust otsekohe, et tema rahutu loomus andis põhjust talle seesugust nime panna, siis tuleb arvata, et Ruurik tõeste oma sõja himu poolest teistest vendadest lahku läks. Ka ajalugu kinnitab seda, sest teised vennad kadusivad pea, kuna Ruurik ise valitsejaks sai ja omale hoopis suuremat ajaloolist tähtsust võitis. (Truusmann 1890)

Võrreldes Truusmanni lähenemist teiste arutelus osalejate omadega, paistab silma erinevus kõneviisis. Mitte võib olla, vaid on (või ei ole) - ta ei oleta ega tõlgenda, vaid esitab asju "nii, nagu nad on". Sellisele enesekindlale väljendusviisile lisandub aga ka omamoodi lõpliku seletuse taotlus: ta ei rahuldu üksikute detailide seostamisega, vaid soovib asetada nad ühtsesse kõikehõlmavasse tervikusse. Oluliseks märksõnaks selle terviku loomisel on ajalugu (või täpsemalt ajalooline aeg). Ehkki ka teised arutlejad pidasid "Majaussi kasvandikke" oluliseks ajalooliseks dokumendiks, olid ajalised raamid, millesse nad oma seoseid paigutasid, võrdlemisi hägused; Truusmanni eesmärgiks on loos sisalduva olulise info dateerimine ning ajalisse järgnevusse asetamine.

Viimase heaks näiteks on seletus, mis asjaoludel muistsed vürstid (või nende kaasmaalased) Eestisse võisid sattuda ning sedakaudu ka eestlaste rahvaluulesse jälje jätta. Truusmanni pikk ja kohati detailidesse kaduv narratiiv kõlab umbes nii: ajaloost on teada, et 8.-9. sajandil tegid normannid hulgaliselt sõjaretki Euroopasse, sh ka Eesti alale. On küllaltki võimalik, et neil tekkis siinmail ka püsivaid asustusi, üheks selliseks võis olla Peipsi kandis asunud "Russa vald", mille nimi viitab elanike Rootsi

13 Truusmann viitab väljaandele "Die Berufung Der Schwedischen Rodsen Durch Die Finnen Und Slawen: Eine Vorarbeit Zur Entstehungsgeschichte Des Russischen Staates", B. 2. (1845). 
päritolule. ${ }^{14}$ Sakslaste saabudes pidid selle valla elanikud aga "Ema jõe ja Virts järve taga peidu paika otsima, mida koha nimed tunnistavad. Seal juures jäi neile nende nimi Russ, Russi järele, mis tunnistab, et nad mitte Eestlaste hulgast ei olnud tõusnud vaid Rootslaste maalt välja tulnud" (samas). Sama detailselt seletab Truusmann ka näiteks seda, miks on mälestus neist vürstidest säilinud muistsest Rusti vallast üsna kaugele jääval Järvamaal (jutustaja Rein Ruute on sündinud Öötla vallas, Peetri kihelkonnas, vt Grenzstein 1890b). ${ }^{15}$

\subsection{Eestlased, tšuudid ja impeeriumi loomine}

Veel üheks Truusmanni lähenemise eripäraks on suurem tähelepanu Nestori kroonika tekstile - konkreetsemalt sellele, et kroonika andmeil oli vürstide kutsujate hulgas mitu eri rahvast, sh ka tšuudid, keda sageli eestlaste esivanemateks peetakse. Ükski teine diskussioonis osalejatest tšuudidele ei viita - näiteks Grenzstein vürstide kutsumise lugu edastavas artiklis kujutab sündmust vaid slaavlastesse puutuvana (vt Grenzstein 1890a), sama tendents valitseb ka teistes kaasaegsetes eestikeelsetes impeeriumi ajalugudes (vt nt P. Jakobson 1885: 86). Truusmann lõpetab oma artikli aga justnimelt küsimusega sellest, kas kroonikas mainitud tšuudid võisid olla eestlased. Truusmanni jaatav vastus toetub nii eestlaste seosele Peipsiga (Чудское озеро) kui ka eri allikatest (sh rahvalaulud ja "Kalevipoeg") pärinevatele teadetele eestlaste ja venelaste ajaloolistest kontaktidest:

14 "Selle pärast ei ole sugugi võimata, et Ruurik ja tema vennad veel enne kui neid vürstideks kutsuti, Eesti maal ja Novgorodi maakondades käisivad. Võimalik on ka, et nemad ajuti kuski kohas metsamaades elama asusivad, kõige vägevamalt tunnistab rahva jutt ühest niisugusest asutusest või vallast, mis Peipsi järve õhtu poolse kalda ligidal on olnud. See vald on olnud praeguses Räppina kihelkonnas ja ta oli "Russa vald", ta üle valitses "Russi papa" ehk "papa Russ"” (Truusmann 1890).

15 "Imelik on aga see, kuidas see muinas jutt nende Eestlaste hulgas alal on seisnud, kes Venelastest eemal ja hoopis Eestimaa südames elamas on. Põhjuseks võisivad siin üksi sisemised tingimused olla, nimelt Järvamaa rahva - Eestimaa südame - mitme saja aastane takistamata asumine ühe koha peal, rahuline elu ühest põlvest teise, mida ei rikkunud alalised sõjad ega takistanud hävitavad haigused, katk, külge hakkavad tõbed j.n.e. neil tingimistel oli kõige enam maad Järvamaal, kus veel 13 aasta saja sees Läti Hindreku tunnistuse järel suured ja ilusad külad olivad. Ka meie päivil on seal külad enam rahva rikkamad, kui teistes maakondades Eestimaal. Selle järel otsustades, et koha nimed põhja-homiku poolses jaus Tartu maakonnas Järvamaa omadega ühes on, võib arvata, et see jägu Järvamaa rahvast on Tartumaa piiride seest seie elama asunud, ehk et neil viimastega kuidagi teist viisi ligemat ühendust oli" (Truusmann 1890). 
Arutatav muinas jutt viib meid viimaks selle küsimuse juurde, kas on Eestlased vürstide kutsumisest osa võtnud. Nestori ütlemise järel olivad pea tegelased vürstide kutsumise juures Tschuudid. Keda tema selle nime all mõtles, on tänini seletamata, aga kahtlemata on selge, et nende hulka ka Eestlased arvatud saivad, kelledest Peipsi järv omale nime sai [---]. Peipsi järvest hommiku pole kunni Ilmeni järveni elasivad kord praeguste Eestlaste sugulased Vodjalased ja lõuna homiku pool, keset Eestlaste asutusi Isborski linnas, hakkas Ruuriku noorem vend Truvor valitsema. Kui Ruuriku järel tulijate Olegi ja Igori sõdadest rääkides Tschuudisid nimetatakse, siis võisivad nende hulgas ka Eestlased olla, kellede vanades lauludes räägitakse mitme aasta pikustest sõdadest, mis nad Venelastega ühes on pidanud. Ka kaupmehena läksivad Eestlased Venelaste maale, nagu näituseks Eesti eeposes Kalevi pojas ühest Kalevi pojast lauldakse, kes Venemaale läks ja seal tubliks kaupmeheks ülesse kasvas. Kalevi teist poega, Eesti rahvuse kangelast, leiame mitu korda teekonnalt Peipsi järve kaudu Pihkva rajadesse, kust ta laudu tooma käis linnade ehitamiseks. (Truusmann 1890)

Üks põhjus, miks Truusmann tšuudide olemasolule viitab, on ehk see, et nii on kerge tuua esile teiste arutelus osalejate argumentatsiooni vastuolulisust: kui eestlased on tšuudid, siis idee "eestlastest kui vürstide päritolurahvast" seaks eestlased üheaegselt kahte rolli, kutsujate ja kutsutute hulka, kroonika tekstis on aga selgelt mainitud, et vürstid kutsuti välj a st . Samas on oluline, et ehkki Truusmann rõhutab eestlaste kuulumist impeeriumi vaatepunktist omade hulka, ei soovi ta kindlasti aktualiseerida venestust toetavaid Nestori kroonika lugemisi, mis rõhutasid tšuudide allutatust slaavi hõimudele: "Vene vürstidele andami maksmine ja õigeusu vastuvõtmine valmistas lätlasi ja tšuude ette täielikuks ühinemiseks vene rahvaga" (Jefgard Tšešihhin "Balti krai lühike ajalugu" (1884), op. cit. Karjahärm 1997: 31-33). Paar aastat varem Eesti Kirjameeste Seltsis peetud ettekandes "Kust ja kudas algab Eesti rahva ajalugu" rõhutas Truusmann just vastupidist: ehkki Venemaale venelaste keskele jäänud soome rahva killud on nüüdseks täiesti venestunud, ei pea oma praegusel asualal (s.o venelastest eraldi) elavad eestlased sellist saatust kartma (Truusmann 1887).

Selline rõhk eestlaste iseolemisele suhestab Truusmanni ühe hoopis teise viisiga tšuudide rolli mõtestamiseks. Konkreetsemalt pean ma silmas kaht Riias õigeusu kiriku poolt väljaantud trükist: 1855. aasta "Eesti rahva kalendris" olev pikem ülevaade "Teädus Lätlastest ja Eestirahvast, enne kui Saksad nende maale tullid" ning kooliõpetaja ja õigeusu preestri Jakob 
Lindenbergi kirjutatud ajalooõpik "Venne rahvas ja Venne riik" (1872). Need kirjutised ei rõhuta mitte üksnes eestlaste kuulumist tšuudide hulka, vaid ka seda, et nad ei olnud teiste rahvaste suhtes allutatud positsioonis. Nii märgib kalender, et eestlased olid tol ajal "üheks Vene Rigi pea- ja esimesest otsast ellava rahva kokko loetud, ausaks jaoks" (Eesti rahva kalender 1855: 44), ning Lindenberg kujutab protsessi demokraatliku nõupidamisena: "Venne, Some ja Eesti rahva vannemad tullid kokko nõu piddama, kust õiget kohtumõistjat saada" (Lindenberg 1872: 9). On üsnagi raske hinnata, kas ja kuivõrd need teosed õigeusuringkondadest väljaspool üldse levisid. Ainsaks viiteks, mis mul on õnnestunud leida, on see, et Lindenbergile toetudes on vürstide kutsumise lugu oma lugemikus tutvustanud ka Carl Robert Jakobson $^{16}$ (1876: 1-2). Siiski võib olla üsnagi kindel, et Truusmann, kes oli õigeusklik ning osa oma haridusest saanud Riia õigeusklikes õppeasutustes (1869-1879 õppis ta Riia Vaimulikus Koolis ning Riia Vaimulikus Seminaris), oli sedalaadi käsitlusviisiga tuttav.

Nende teoste kontekstualiseerimiseks on hea meeles pidada Alo Rauna tõdemust, et venestuseelsel ajal puudus õigeusu kirikul riiklik tugi Läänemere provintsides tegutsemiseks (Raun 2009: 147) - viidatud raamatud (sh ka Jakobsoni lugemiku esmatrükk) pärinevad aga just sellest ajast. Seega võib eeldada, et need ajalootõlgendused olid õigeusu kiriku teadlik katse end eestlastele lähendada - nende viis rõhutada, et eestlaste ja venelaste suhted on olnud juba ammustest aegadest väga head. Samuti näib tõenäoline, et 1885. aasta järgsel ajal toetus ka õigeusu kirik ametlikult pigem Tšešihhini stiilis venestavatele ajalookäsitlustele (vt Karjahärm 1997) ning varasemad tõlgendused olid vähemalt ametlikust retoorikast kõrvale jäetud.

Viimane omakorda muudab Truusmanni positsiooni vägagi ambivalentseks. Ühelt poolt toob ta esile, et tema sekkumine diskussiooni on tingitud "Venemaal elavate venelaste arusaamatusest", teisalt ei toetu edastatav sõnum mitte ametlikule seisukohale, vaid aktualiseerib üht tõlgendust, mis pakub alternatiivi nii venestust õigustavatele ajalookäsitlustele kui ka neile, kes kujutasid impeeriumi loomisloo kontekstis üksnes venelasi (nt P. Jakobson 1885, aga ka Grenzstein 1890): impeeriumi algus hõlmas mitmete rahvuste ja keelte koostööd ning kõigil neil rahvastel on õigus oma eripärade säilitamisele.

16 Ants Viires oletab, et 1855. aasta kalendris ilmunud artikkel võis anda Jakobsonile inspiratsiooni tema valguse-, pimeduse- ja koiduaja narratiivi loomiseks erinevalt nn saksa vaatepunktist kirjutatud ajalugudest, kus sakslaste ja ristiusu tulekut käsitleti valguse aja algusena, kujutas see käsitlus sakslaste tulekut just hädade ja õnnetuste algusena. Viide Lindenbergi raamatule ei ole siiski otseseks tõendiks Viirese oletuse paikapidavusele - Lindenbergi raamat ilmus neli aastat pärast Jakobsoni esimest isamaakõnet. 


\section{TAGASI ALGUSPUNKTI: VOLDEMAR LURICH (JA MIHKEL KAMPMANN)}

Diskussiooni avanud kirjutises esitleb Kampmann ennast kui muinasjutu "Majaussi kasvandikud" kogujat ja avastajat. Tänu Grenzsteinile (1890b) aga teame, et loo esimeseks kirjapanijaks oli hoopis jutustaja Rein Ruute lapselaps - 17-aastane äsja gümnaasiumi lõpetanud Voldemar Lurich (seesama, kes pani kirja teisendi VL1). Ka tähelepanek peategelaste ja vene vürstide nimede vahelisest sarnasusest pärines Lurichilt.

Nagu Kampmann, oli ka Lurich Jakob Hurda rahvaluulekorrespondent, ent kui Kampmann ühines Hurda aktsiooniga juba selle algul 1888. aastal, ${ }^{17}$ siis Lurichi esimene saadetis jõudis Hurdani 1890. aasta veebruaris - vaid mõni kuu enne diskussiooni puhkemist. Tänu Grenzsteinile teame, et materjale selle esimese saadetise jaoks asus ta koguma vähemalt aasta varem "Majaussi kasvandikud" said kirja 1889. aasta lihavõtete ajal. Grenzstein mainib ka, et noormees näitas oma kirjapanekuid kõigepealt kohalikule kooliõpetajale Peeter Koidule (teisendi PK kirjapanija) ning 1890. aasta algul ka kohalikule köstrile Mihkel Kampmannile. On üsnagi tõenäoline, et just Koit oli see, kes Lurichi (kui alustava rahvaluulekoguja) ning Kampmanni (kui kogenud rahvaluulekoguja) omavahel kokku viis, ning ehk just Kampmanni tagasiside andis Lurichile julgust oma kogutu lõpuks ära vormistada ning Hurdale saata.

Eelnevast tuleb ühelt poolt esile see, et suur osa vaadeldava meediasündmuse osalistest polnud mitte üksnes omavahel tuttavad, vaid elasid piisavalt lähestikku, et teemat ka suusõnaliselt arutada. ${ }^{18}$ Teisalt nähtub, et sündmuse alguspunktiks polnud mitte rahvaluulekoguja kohtumine allikaga, vaid kogenud kirjamehe kohtumine 17-aastase noormehega. Nende suhe ei olnud kindlasti egalitaarne, kõige õigem on seda kirjeldada ehk mentorlussuhtena - ning viimast üsnagi avaras mõttes, kuna lisaks nõuannetele seoses rahvaluulekogumise ja kogutu vormistamisega toetas

17 Enne seda saatis ta rahvaluulelist materjali ka ajalehtedele. Olevikule saadetud materjalid paiknevad Hurda kogus: H, R 4, 99-102; H, R 6, 583-586 (Hurda kogumisaktsiooni tulise toetajana saatis Grenzstein kõik varasemalt Olevikku laekunud rahvaluulesaadetised 1888. aastal Hurdale ning jätkas ka hiljem materjalide vahendamist). Ühes kirjas Olevikule nimetab ta ka Meelelahutajale saadetud kaastöid, vt H, R 6, 584. Ühes kirjas Hurdale mainib ta, et alustas kogumistööd juba 1881. aastal oma lõbuks (H II 11, 424d, 2. märts 1890).

18 Näib, et ainus, kes ühtegi teist osalenut isiklikult ei tundnud, oli Johan Pihlakas. 
Kampmann ka Lurichi tööotsinguid. ${ }^{19}$ See, et Lurichi kogutud lugu ning temalt pärinev tõlgendus jõudis avalikku kirjaruumi ilma igasuguse viiteta tema olemasolule, oli vaid üks osa Kampmanni ja Lurichi omavahelise suhte iseloomust: tema oma nime all poleks lugu ilmselt avaldatud (meenutagem, et isegi Kampmannil õnnestus see alles teisel katsel). Samas on huvitav, et Lurich ei loovutanud Kampmannile üksnes ajaleheteksti kirjutamise au, vaid teksti kui terviku - "Majaussi kasvandikke" Lurichi esimeses Hurdale saadetud rahvaluulekogumikus ei ole (eeldatavasti tugineb Hurda kogus olev teisend MK1 Lurichi käsikirjale) ${ }^{20}$.

Kui otsida vastust küsimusele, mis oli see, mis pani Lurichit nägema seost muinasjutu peategelaste ja Vene vürstide nimede vahel, võib välja tuua kaks asjaolu. Esiteks haridus: Lurich oli 17-aastane, äsja Hugo Treffneri gümnaasiumi lõpetanud noormees. Hariduslik taust on oluline nii keeleliselt (tänu heale riigikeele oskusele oli tema lugemisvara tavaeestlase omast avaram), sisuliselt (gümnaasiumi programmi kuulus kindlasti ka ülevaade impeeriumi ajaloost) kui ka ideoloogiliselt (kontekst, kus ta Vene impeeriumi asutamislooga kokku puutus, soosis meeldejätmist ning rõhutas narratiivi seotust tema enda kui teatud riigi kodanikuga).

Lisaks sellele võime aga täheldada Lurichi huvi ajalooga seotud folkloori vastu. Näiteks tema kõige esimeses rahvaluulesaadetise ${ }^{21}$ on mitmeid tugevate romantilise ajalookirjutise mõjudega lugusid. Oma alandlikus vas-

19 Kõigis rahvaluulesaadetiste kaaskirjades palub Lurich Hurdalt abi Peterburis töö leidmiseks (vt EKLA f 43, m 14:10, 5 kirja 1890. aastast). Kampmann toetas Lurichi otsinguid Hurdale saadetud positiivse soovituskirjaga (vt M. Kampmann J. Hurdale 2. märtsil 1890, H II 11, 424a/b). Näib, et Hurt saatis Lurichile küll mitmeid julgustavaid kirju, kuid tööd talle siiski ei leidnud.

20 Kui viimane oletus on õige, võiks see tekst anda meile ligipääsu diskussiooni reaalse alguspunkti juurde. Nimelt on teisendi MK1 suhe Sakalas avaldatud tekstiga (teisendiga MK2) mitmes mõttes problemaatiline. Esiteks on ajalehes ilmunu narratiivselt tunduvalt sidusam. Teiseks on aga ka sisulisi erinevusi, näiteks puudub teisendis MK1 viide vendade välismaale kuningaks minemisele ning nimeandjaks pole mitte majauss, vaid eestlaste vanem. Loomulikult on võimalik, et Kampmann küsis Lurichilt suuliselt täpsustusi, kuid tõenäolisem näib, et ta muutis teksti teadlikult loetavamaks ning tõlgendusega sidusamaks. On üsnagi kõnekas, et nime Трувор viimaseks vokaaliks on kõigis diskussiooni-eelsetes kasutuses $o$, kuid diskussiooni siseneb ta kirjapildiga Truuvaar. Ka diskussiooni kontekstis kasutab topelt $a a$-d üksnes Kampmann, Grenzstein ja Truusmann kasutavad vaheldumisi variante Truvor ja Truvar (o-ga variant on ülekaalus).

21 H III 2, 749/72 < Väike-Maarja khk (1890), tõenäoliselt on suurem osa selle sisust kogutud samal ajal kui "Majaussi kasvandikud". 
tuses Hurda järelepärimistele ${ }^{22}$ kirjutab Lurich, et oli ka ise nende lugude rahvapärasuse osas kahtleval seisukohal, näiteks loo "Kirjavane" ${ }^{23}$ hõlmamist põhjendab ta sellega, et usaldas informanti, kes ütles, et "et ta teda küll kuskil lugenud pole, vaid ühe teise käest kuulis". ${ }^{24}$ Kuid "Kirjavane" on korjanduse kõige esimene pala - näib, et saadetist vormistades pidas Lurich just seda millekski, mille kaudu end Hurdale tutvustada.

\section{6. "VÄIKESE RAHVA SUURED LOOD”}

Võib väita, et minu artikli keskmes oleva diskussiooni lähtepunkt on võrdlemisi juhuslik: üks rahvaluulekogujana kätt prooviv noormees avastas seose koolis õpitu ja rahvaluulekogumise käigus leitu vahel. Seose tekkimises pole iseenesest midagi ebatavalist - mitmed teisedki Hurda korrespondendid täiendasid kogutud materjale omapoolsete tõlgenduste või kommentaaridega (ses suhtes on Lurichi ja Pihlaka kommentaarid Russi nimele üsnagi tavapärased). Siinkohal on aga kõnekas see, et tõlgendus ei jäänud koguja ja Hurda erasuhtluse tasandile, vaid jõudis avalikku ruumi. Seega võib öelda, et tegu oli hästi ajastatud juhusega.

Aga selle juhusliku, konkreetse ajahetke ning seal toimetavate inimestega seotud tõlgenduse puhul on põnev, et avaramas ajaplaanis ei tundugi see enam nii üksik või juhuslik. Nimelt pole tegu üldsegi ainsa katsega kasutada seda Nestori kroonika lõiku, et luua väikesele rahvale "suurt lugu" (vrd Kalmre 2012). Näiteks rõhutab soomeugrilaste osa Vene riigi rajamises Johannes Jaanus oma 1925. aastal ilmunud Petseri ajalugu käsitlevas raamatukeses (vürstide nimed on ta eestistanud kui Rüärääk, Siniuss ja Truuvaar, vt Jaanus 1925: 12-13). Ka 1932. aastal ilmunud "Eesti rahva ajaloos" on peatükk, mis käsitleb skandinaavlaste ja soome sugu hõimude osa Vene riigi asutamises; autor viitab ka otseselt "Majaussi kasvandikele"

22 Avalik noomitus on 59. aruandes: "Aga väga kahetseme, et auus saatja üles kirjutades oma tarkust juure on lisanud. Selle läbi on mõni jutustus koguni kahtlaseks saanud. Niisugusid ei või meie mitte pruukida. Kahetsemisega oleme neile juttudele oma iseäralise märgi juurde pannud. [---] Seda üteldes rõõmustame ühtlasi, et lahke saatja rohke materjaali hulgas ka päris ja õiget rahvamaterjaali küll on, mis tänuga saame tarvitama" (Hurt 1890). Viisist, kuidas Lurich Hurdale vastab, jääb mulje, et Hurt on saatnud talle ka isikliku kirja, kus ta on täpsustanud, millised lood tema arvates problemaatilised on.

${ }_{23}$ Vt H III 3, 740/58. Lugu kõneleb "vana viru pealiku Kirjavane" surmast võitluses vaenlaste vastu.

24 V. Lurich J. Hurdale 14. märtsil 1890, EKLA f 43, m 14: 10, 1 2/3-2/4. 
(küll rõhutades, et tegu on rahvaluulelise võltsinguga ${ }^{25}$ ) ning toetab etümoloogiat Russ < Rootsi (vt Libe 1996 [1932]). Kuid mitmeid näiteid võib leida ka 21. sajandi meediast. Mõned neist on humoorikad (Eesti Ekspressis ilmunud muistsete eesti kuningate ja vene hõimujuhtide kirjavahetus, vt Muinas-Eesti 2013), teised tõsiteaduslikumad. Näiteks tutvustab Heiki Suurkask (2010) uurimust, mille järgi Rjurikovide DNA-analüüs viitab nende soome-ugri taustale, ka pakub ta välja, et mereks võib olla Peipsi järv. Pekka Erelt (2010) ja Toivo Kempi (2010) käsitlevad üldisemalt soomeugrilaste osa Vene riigi rajamises. Oma koha on kolm vürsti leidnud ka Vigala Sassi mütoloogias (tema kasutab nimekujusid Sini Siniuss, Inmar Truuvaar ja Helga Rüärääk, vt nt Heintalu 2006: 304) ning Ali Kikkas on loonud sellest sündmusest lähtuvalt näidendi "Majahussi kasvandikuq. Seto näütemäng”26.

Näiteks on põnev, et Eesti Ekspressi kirjutis kasutab samu nimekirjusid mis "Majaussi kasvandikudki”, samas viitab kommentaator "öö”, et "Rjuriku nimi selle algsel, eestipärasel kujul oli Rüarääk”27 - asetades nii dialoogi kaks võimalust Rjuriku nime eestipärastamiseks.

Kõik need näited ei ole otseselt seotud majaussi looga (otsene seos on olemas Juhan Libe kirjutisel, Eesti Ekspressi lool ja Ali Kikkase näidendil), enamuses toetuvad nad üldisemalt Nestori kroonikale ning selle võimalikele tõlgendustele. Mitmel juhul vastandutakse otsesõnu nendele Nestori kroonika lugemistele, mis tšuudide panust vähendasid (nt Truusmann 1890, Jaanus 1925, Libe 1996 [1932]). Lisaks on oluline seegi, et 1890. aasta diskussioon ei ole seesuguse tõlgendustraditsiooni algupunkt - oluliseks mõjutajaks on kindlasti eelpool viidatud õigeusklikud väljaanded (Lindenberg 1872, Eesti rahva kalender 1855), kuid võimalik, et on veel midagi, milleni ma pole jõudnud.

25 Viitasin eelnevalt, et vaadeldav diskussioon kuulus ajajärku, mil ajaloo- ja folkloristikateadus olid omavahel läbi põimunud; Libe käsitlus esindab väga selgelt nn usaldamatuse ajajärku (vt Jaago 2014).

26 http://www.seto.ee/Majaussi-Kasvandikuq.html.

27 http://ekspress.delfi.ee/news/paevauudised/muinas-eesti-ekspresseestlased-laksid-vene-riiki-juhtima?id=65712682\&com $=1 \& \mathrm{reg}=0 \& \mathrm{no}=0 \& \mathrm{~s}=1 \#$ com ment-top. Vaadatud 1.11.2015. 


\section{LÕPETUSEKS}

Alustasin oma artiklit küsimusega sellest, mis tingis selle loo aktualiseerimise. Analüüsis olen ühelt poolt rõhunud ajastukontekstile, s.o venestuse mõjule, kuid viimase toime oli võrdlemisi vastuokslik. Nii lülitub Grenzstein küll arutellu tõdemusega, et "vürstid võisid olla eesti päritolu", kuid tutvustab sealjuures lugejale venestusmõjulist käsitlust kroonikatekstist. Aga just see, eestlaste/tšuudide olemasolu eirav tõlgendus andis talle võimaluse eestlaste asetamiseks hoopis teise rolli. Truusmann lükkab Grenzsteini hüpoteesi ümber, kuid teeb seda aktualiseerides kroonikatõlgenduse, mida ametlikus käibes enam ei tunnustatud.

Laiemas plaanis on ehk paradoksaalne, et ajal, kui eesti keel oli ametlikust kasutusest peaaegu täielikult välja tõrjutud, tekkis ajakirjanduses diskussioon, mille keskmes oli eesti keele põhine tõlgendus impeeriumi alusmüüdist. Teisalt võib ka väita, et just keelelise situatsiooni eripärad tegid selle sündmuse üldse võimalikuks. Tähendas ju vene keele tähtsuse tõus (sh venekeelne kooliharidus) seda, et vene keelt oskavate eestlaste hulk suurenes ning seega suurenes ka nende inimeste hulk, kes võisid lisaks eestikeelsele kirjasõnale tarbida ka venekeelset. Et aga kokkupuude uue keeleruumiga jäi pigem pealiskaudseks, pole ehk imestada, et otsiti võimalusi kultuure ja keeli ühendavateks tõlgendusteks; ning et tulemuseks ei olnud mitte teise kultuuri mõistmine, vaid oma rahvale "suure loo" loomine. 


\section{KIRJANDUS}

Arukaevu, Jaanus 1999 = Uus katse hinnata Ado Grenzsteini rolli Eesti ajaloos. Ajaloo Instituudis 28. jaanuaril 1999 toimunud seminari ettekanded ja arutelu. (Seminaril osalesid: Krista Aru, Jaanus Arukaevu, Ea Jansen, Toomas Karjahärm, Jaan Undusk.) - Tuna, nr 2, lk 111-125.

Brüggemann, Karsten 2010. Lõpp venestusele. Ühe vaieldava uurimisparadigma kriitika. - Vene impeerium ja Baltikum: venestus, rahvuslus ja moderniseerimine 19. sajandi teisel poolel ja 20. sajandi alguses II. Toim. T. Tannberg, B. Woodworth. Tartu: Eesti Ajalooarhiiv, lk 360-374.

Eestimaa Kubermangu Teataja 1890 = Интересное эстонское предание. Эстляндские губернские ведомости, 28.06.

Eesti rahva kalender 1855 = Teädus Lätlastest ja Eestlastest, enne kui Saksad nende maale tullid. - Eesti rahwa kalender se 1855 aasta peale pärast J. Kristuse sündimist. Riia: Mülleri trükikoda, lk 33-50.

EMj I 2009 = Eesti muinasjutud I: 1. Imemuinasjutud. (Monumenta Estoniae Antiquae V.) Koost. ja toim. R. Järv, M. Kaasik, K. Toomeos-Orglaan. Tartu: Eesti Kirjandusmuuseumi Teaduskirjastus.

Eisen, M[atthias] J[ohann] 1877. Eesti-, Liivi- ja Kuramaa ajalugu. Muistsest ajast meie ajani. Kõigile isamaa armastajatele üles pannud ja välja annud M. J. Eisen. Tartu: Schnakenburg.

Erelt, Pekka 2010. 300 aastat Venemaa ühendamisest Eestiga? - Päevaleht, 10.10.

Grenzstein, Ado 1890a. Ruurik, Sineus, Truvar. - Olewik, 09.07.

Grenzstein, Ado 1890b. Majaussi kasvandikud. - Olewik, 16.07.

Heintalu, Aleksander 2006. Estide (tšuudide) hingestatud ilm II. Sõnade seletus. Männisalu.

Hurt, Jakob 1879. Pildid isamaal sündinud asjust. Tartu: K. Mathiesen.

Hurt, Jakob 1890. Viieskümnes üheksas aruanne Eesti wanawara korjamisest ja keelemurrete uurimisest. 13. märtsil 1890. - Olewik, 19.03; Postimees, 28.04.

Hurt, Jakob 1989 [1871]. Mis lugu rahva mälestustest pidada. - Mida rahvamälestustest pidada. Artiklite kogumik. Toim. Ülo Tedre. Tallinn: Eesti Raamat, lk 9-25.

Jaago, Tiiu 2014. Rahvaluule, ajalugu ja "pärimuslik ajalugu”. Vaade valdkonnaseostele rahvalaulu "Eesti mees ja tema sugu" uurimuste näitel. - Keel ja Kirjandus, nr 6, lk 418-435.

Jaanus, J[ohannes] M. 1925. Petserimaa endisest ajast. Sissejuhatus J. M. Jaanus'e ajaloolisest jutustusest: "Igumen Kornelius”. Walk: J. \& O. Lepiku trükk.

Jakobson, C[arl] R[obert] 1875. Kooli lugemise raamat. 3 jagu. Tartu: H. Laakmann. Jakobson, P[eeter] 1885. Ajalugu Eesti alamatele koolidele. Rakvere: G. Kuhs.

Jung, Jaan 1891. Weel kord Eestlaste ussiusust ja Ruuriku muinasjutust. - Olewik, 21.10 .

Kalmre, Eda 2012. Väikese rahva "suured lood" - rahvajuttude kaudu konstrueeritud eneseesitlusest. - Keel ja Kirjandus, nr 5, lk 321-334. 
Kampmann, Mihkel 1890. Majaussi kaswandikud. - Sakala, 9.06.

Karjahärm, Toomas (tlk, toim.) 1997. Venestamine Eestis 1880-1917. Dokumente ja materjale. Tallinn.

Karjahärm, Toomas; Andres Adamson (koost.) 2008. Eesti ajaloo pöördepunktid: dokumente ja materjale vene õppekeelega gümnaasiumile. Tallinn: Argo.

Karjahärm, Toomas 2012. Vene impeerium ja rahvuslus: moderniseerimise strateegiad. Tallinn: Argo.

Kempi, Toivo 2014. Kiievi-Vene: legendid ja tõsilood. - Lääne Elu, 20.03, 22.03, 24.03.

Kikas, Katre 2013. Ajakirjandus Jakob Hurda ja Matthias Johann Eiseni tegevuse mõtestajana. - Keel ja Kirjandus, nr 5, lk 333-350.

Kukk, Kristi 2009. Vene küsimus eesti ajalookirjutuses. - Vene impeerium ja Baltikum: venestus, rahvuslus ja moderniseerumine 19. sajandi teisel poolel ja 20. sajandi alguses. Toim. T. Tannberg, B. Woodworth. Tartu: Eesti Ajalooarhiiv, lk 191-206.

Koit, Peeter 1890. Majaussi kaswandikkude... - Olewik, 30.07.

Körber, Carl 1860. Mailma aiaramat, kus sees on, mis mailma algmissest Ma peäl on sündinud: Kuningattest, Madest, söddadest n. t. s. mitme pildidega ärraselletud. Tartu: H. Laakmann.

Libe, Juhan 1996 [1932]. Vene riigi rajamine. Skandinaavlaste ja soome sugu hõimude osa selles. - Eesti rahva ajalugu 1. Toim. J. Libe, A. Oinas, H. Sepp, J. Vasar. Tallinn, lk 57-65.

Lindenberg, J[akob] 1878 Wenne rahvas ja Wenne riik. Riia: E. Plates.

Lurich, Voldemar 1890. Majaussi kaswandikud. - Olewik, 22.10.

Miller, Alexey 2009. Venestus või venestused? - Vene impeerium ja Baltikum: venestus, rahvuslus ja moderniseerumine 19. sajandi teisel poolel ja 20. sajandi alguses. Toim. T. Tannberg, B. Woodworth. Tartu: Eesti Ajalooarhiiv, lk 33-49.

Muinas-Eesti 2013 = Muinas-Eesti Ekspress: Eestlased läksid Vene riiki juhtima. Eesti Ekspress, 23. II. http://ekspress.delfi.ee/kuum/muinas-eesti-ekspresseestlased-laksid-vene-riiki-juhtima?id=65712682 (1.11.2015).

Pihlakas, Johan 1890. Majaussi kaswandikud. - Olevik, 17.09.

Raun, Toivo Ülo 2009. Venestamine Eestis 19. sajandi teisel poolel ja 20. sajandi algul. - Vene impeerium ja Baltikum: venestus, rahvuslus ja moderniseerumine 19. sajandi teisel poolel ja 20. sajandi alguses. Toim. T. Tannberg, B. Woodworth. Tartu: Eesti Ajalooarhiiv, lk 113-165.

Saal, Andres 1893. Üleüldine Isamaa ajalugu I. Eestlaste ajalugu, kõige wanemast ajast nende priiuse kautamiseni. Rakvere: R. Erna.

Suurkask, Heiki 2010. Meie hõimuvelled Kremlist: Rjurik ja tema järglased. -Eesti Päevaleht, 19.08 .

Truusmann, Jüri 1887. Kust ja kudas algab Eesti rahwa ajalugu? Kõne peetud Eesti kirjameeste seltsis 3. Jaanuaril 1887. - Oma maa: teaduste ja juttude ajakiri, nr 2, lk 80-84, nr 4, lk 136-141, nr 5, lk 200-204.

Truusmann, Jüri 1890. Eesti muinasjutt Ruurikist, Sineusist ja Truworist. - Walgus, 05.09 . 
Undusk, Jaan 1995. Hamanni ja Herderi vaim eesti kirjanduse edendajana: sünekdohhi printsiip. - Keel ja Kirjandus, nr 9, lk 577-587, nr 10, lk 669-679, nr 11, lk 746-756.

Undusk, Jaan 1997. Kolm võimalust kirjutada eestlaste ajalugu. Merkel - Jakobson - Hurt. - Keel ja Kirjandus, nr 11, lk 721-734, nr 12, lk 797-811.

Viires, Ants 2001. Eestlaste ajalooteadvus 18.-19. sajandil. - Tuna, nr 3, lk 20-36.

Valk, Ülo 2008. Saksad ja varavedajad: eesti muistendite sotsiaalsest orientatsioonist. - Kes kõlbab, seda kõneldakse. Pühendusteos Mall Hiiemäele. Koost. E. Kalmre, E.-H. Västrik. Tartu: Eesti Kirjandusmuuseumi Teaduskirjastus, lk 57-73. 


\section{LISA}

\section{Viidatud narratiivid}

MK1 - H II 11, 433/4. Teisendi saatis Hurdale Mihkel Kampmann, kes tõenäoliselt sai loo Voldemar Lurichilt. Jutustajaks on tõenäoliselt Rein Ruute. Lugu on fragmentaarne ja üsnagi romantiseeritud.

MK2 - avaldatud Kampmann 1890. Tõenäoliselt tugineb teisendile MK1, kuid on mõnevõrra terviklikum. Sama romantilises keeles.

AG - avaldatud Grenzstein 1890b. Jutustajaks Rein Ruute. Võrreldes sama jutustaja esitusele tuginevate teisenditega MK1 ja MK2 on lugu vägagi lihtsas keeles. Grenzstein on oma artikli käsikirjalise versiooni saatnud ka Hurdale, H II 11, 889/907.

PK - avaldatud Koit 1890. Jutustajaks Mari Silbert. Väga fragmentaarne, üles on märgitud vaid narratiivi põhikohad - vendade nimed (jutustaja mäletab ühte), ussi värv ja välismaale minek. Lugu on leitav ka Grenzsteini kirjakogust (EKLA, f 38, m 12: 219).

JP1 - avaldatud Pihlakas 1890. Üleskirjutaja Johan Pihlakas kuulis lugu lapsepõlves, aga ei mäleta enam, kellelt. Tegu ei ole narratiivi, vaid majausside traditsiooni kirjeldusega.

JP2 - avaldatud Pihlakas 1890. Üleskirjutaja Johan Pihlakas kuulis loo oma vanaisalt Juhan Brandvahtilt. Loos puuduvad vendade nimed.

VL1 - avaldatud Lurich 1890. Allikaks Minna Soop, kes kuulis loo lapsepõlves Ann Lüiterilt.

VL2 - avaldatud Lurich 1890. Allikaks Minna Soop, kes kuulis loo Eeva Konnilt. Tegu pole terviknarratiivi, vaid ühe teisendit VL1 täiendava motiiviga.

VL3 - H II 12, 470/3. Teisendi VL1 arhiiviversioon. Peamiseks erinevuseks on allikaandmete puudumine. 


\section{Summary}

\section{FOLKLORE AND HISTORY IN A MEDIA DISCUSSION: A NARRATIVE ABOUT SINIUSS, TRUUVAAR AND RAHURIKKUJA}

In the summer of 1890, several Estonian newspapers published articles about the possible national and historical background of the folktale called Majaussi kasvandikud ('The boys brought up by the house snake'). The event started after a schoolteacher Mihkel Kampmann published the narrative in the newspaper Sakala and insisted that the names of the protagonists (Rahurikkuja, Siniuss, Truuvaar) looked suspiciously similar to the ancient kings of Russia mentioned in Primary Chronicle (discussants use the earlier name Nestor's Chronicle). The discussion that followed focused on the question whether there could be a possible connection between those two narratives (the Estonian folktale and the Russian chronicle), and if so, could the Estonian folktale offer new insights into the matter.

In analysing this discussion I was not interested in the historical (or folkloristic) truth behind the possible connection of the two narratives or the origins of the folktale. I enquired why this folktale was found so relevant and what were the questions and problems that the participants hoped to solve with the help of the narrative.

It is important that the discussion took place in the period of very intensive folklore collecting - at the time when matters concerning folklore where quite often discussed in newspapers. Another important contextual factor was the so-called Russification, which introduced the need to rethink the entire role of the Estonian nation in the Russian Empire. I propose in the article that the discussion was one attempt to do it. However, the solution(s) it hinted at were multiple and ambivalent due to divergent attitudes towards Russification.

KEY WORDS: 19th century, folklore studies, folktales, history of journalism, Russification 